\title{
OF DENSITY AND DECLINE: REFLECTIONS ON ENVIRONMENTAL LAW TEACHING IN THE UK AND ON THE CO-PRODUCTION OF ENVIRONMENTAL LAW SCHOLARSHIP
}

\author{
Steven Vaughan, Alexandru Baltag, Ryan Brun, Rory Buttle, Caoimhe Creed, Arianne \\ Delos Santos, Nia Evans, Jekilyah Gibson, Milon Goh Wei Ming, Etta Grilli, Kiran \\ Makwana, Cassie Steiert, Kathryn St John, and Alexandra Weiner ${ }^{1}$
}

\begin{abstract}
This chapter was written by the module convenor of a final year undergraduate Environmental Law course in the UK and his students. In it, we ask a series of questions about the teaching of environmental law in the UK. We do this, in part, by drawing on data we collected from the top 100 UK law school websites and survey responses from UK environmental law scholars. We show what we think is a decline in the provision of environmental law teaching in the UK and stasis in student numbers over time. We explore perceptions that environmental law is 'soft', asking if this is because environmental law scholars are seen as liberal 'tree huggers' and/or because environmental law is thought to be more about values than about law. We also look at employability as a mission of modern universities, asking if studying environmental law at university can only ever be a 'nice to have' in this context. We ask more questions than we can answer, but hope this piece is the start of an important debate. And we hope it will encourage other environmental law academics to do this sort of action research with their students.
\end{abstract}

\section{KEYWORDS}

environmental law teaching; legal education; qualifying law degree; co-production

\section{Introduction}

We are the UCL LLB Environmental Law class of 2018: its module convenor (Steven) and thirteen of his final-year undergraduate students. This chapter is about a piece of research we undertook together: about the methodology of that co-production exercise; and about the state of teaching of environmental law in the UK. For the latter, we draw on a dataset we created which was generated through data taken from the top 100 UK law school websites, and survey responses from 49 UK-based environmental law scholars. We use the data to ask some hard questions about if, how, and where the teaching of environmental law has stagnated or been marginalised. This is, in effect, a 'state of the nation' account. We situate the exposition of our website data with the perceptions held by UK environmental law educators about environmental law teaching, what they feel to be the perceptions of the subject by their students, the challenges educators think the subject currently faces, and the challenges it might face going forward. Our chapter unfolds in five parts. It begins by situating what we did in the wider scholarship in the UK on environmental law teaching. Part two sets out the methodology of our co-production. Part

\footnotetext{
1 All of University College London. Please contact: Professor Steven Vaughan, Faculty of Laws, Bentham House, Endsleigh Gardens, London, WC1H 0EG; steven.vaughan@ucl.ac.uk We are grateful to Maria Lee, Richard Moorhead, Eloise Scotford, and Elen Stokes for comments on an earlier draft. The usual disclaimer applies.
} 
three summarizes what we found. Part four looks at why teaching environmental law might be challenging. Finally, we conclude with some reflections on our data.

\section{Scholarship on Environmental Law Teaching in the UK}

Scholars of UK environmental law have reflected on the 'field' relatively frequently (though also relatively recently). They have debated its contours and framed its limits; traced its origins and analysed its development; compared and contrasted their scholarship with that of others in different areas of law. ${ }^{2}$ Those scholars appear to be both hesitant and introspective about environmental law as a discipline and about the quality, quantity and coherency of environmental law scholarship. There is, however, strikingly little written about the teaching of environmental law in the UK. ${ }^{3}$ The primary reference point is work undertaken in the early 2000s by Stuart Bell, Donald McGillivray, Andrea Ross-Robertson, and Sharon Turner on behalf of the UK Centre for Legal Education (hereafter, the 'UKCLE Report'). ${ }^{4}$ One of the prompts for their interest and for the study undertaken was the (at that time) 'deafening silence coming from the literature' reflecting on the teaching of environmental law. ${ }^{5}$ The intervening 17 years have been equally quiet, punctuated by the infrequent noise of a mere handful of papers. ${ }^{6}$ Whatever the underlying reasons for the lack of interest, engaging in careful and critical debate about the teaching of environmental law has value. Failing to reflect on teaching indicates a blindness to the role of teaching as generative of cutting-edge research. ${ }^{7}$ Such failure privileges what academics do with writing over what academics do with students, and this cannot be right. We might further suggest that some form of ethical obligation is at play. If part of what academics do with their students is to teach them how to problematize environmental harms, and if some of those students go on to tackle these problems as environmental lawyers or activists or policymakers, then where, how, and why we teach environmental law can have significant purchase beyond the classroom. As Eloise Scotford and Steven Vaughan have argued elsewhere, "In the way that we frame, phrase and organize our environmental law classes, we are defining the approach to our subject for future environmental lawyers and future citizens, and also expressing a (usually unarticulated)

\footnotetext{
2 See: Colin Reid, 'Environmental Law: Sifting through the Rubbish' (1998) Juridical Review 236; Elizabeth Fisher and others, 'Maturity and methodology: Starting a debate about environmental law scholarship' (2009) 21 JEL 213), Ole Pedersen, 'The Limits of Interdisciplinary and the Practice of Environmental Law Scholarship' (2014) 26 JEL 423; Gavin Little, 'Developing environmental law scholarship: going beyond the legal space' (2016) 36 Legal Studies 48; Ole Pedersen, Perspectives on Environmental Law Scholarship: Essays on Purpose, Shape and Direction (CUP 2018).

${ }^{3}$ The notable exception is the work of Jane Holder. See: Jane Holder, 'Identifying points of contact and engagement between legal and environmental education' (2013) 40 JLS 541; and Jane Holder, 'Doing the Sustainable Development Dance: Tracing a Critical Route from the Education for Sustainable Development Movement to Environmental Justice in Legal Education’ (2012) 65 CLP 145.

${ }^{4}$ Stuart Bell, Donald McGillivray, Andrea Ross-Robertson and Sharon Turner, 'UKCLE Subject Survey Environmental Law' (UKCLE Report 2002).

5 ibid, 8.

${ }^{6}$ In her work on education for sustainable development, Jane Holder (n 3) uses the UKCLE Report as an introduction to a wider discussion on the problems encountered in environmental law scholarship and methodology, as well as in the teaching of sustainable development. There is also a grouping of papers that explore embedding sustainability into legal education. See, for example: Colin Reid and Nadeem Ali, ESD and the Professional Curriculum (HEA Academy Interdisciplinary Project Report 2010/11); and Jason Lowther and Joanne Sellick, 'Embedding sustainability literacy in the legal curriculum: reflections on the Plymouth model' (2016) 50 The Law Teacher 307.

${ }^{7}$ See, for example: Alisa Miller and others, What is Research-Led Teaching? Multi-Disciplinary Perspectives (GuildHE 2012).
} 
view on the role played by a law school." ${ }^{8}$ Finally, teaching is part and parcel of the everyday experiences of environmental law scholars. As Fiona Cownie and Anthony Bradney have put it, "Whatever else legal academics do, one matter that should concern them is the nature of their lives." "Thinking hard and deep about environmental law teaching can benefit us all. And that is one of the reasons why this topic was chosen for the research co-production exercise underpinning this chapter.

\section{What We Did}

There are two methodologies at play in this chapter. The first relates to the data we draw on in the sections that follow. The second relates to the writing of the paper as a pedagogic co-production enterprise. With respect to the data we use, we have adopted a mixedmethods approach; exploring website data and survey responses. ${ }^{10}$ Information on the teaching of undergraduate environmental law options was taken from UK top 100 university websites in late 2017. A second data set was created for postgraduate modules using information sourced from the websites of the same universities in early 2018 . In midMay 2018, we then launched an online survey aimed at those with current or previous experience of teaching environmental law in the UK. The link to the survey was distributed via: (a) emails to individual academics whose contact details were sourced from the university websites detailing the relevant environmental law modules; and (b) professional associations. In total, 49 responses were received from those teaching environmental law at 38 separate universities. We use anonymised markers below (e.g. "R1", "R22") to identify qualitative data taken from the survey responses.

As a pedagogic enterprise, this paper is the product of a research co-production exercise between a module leader and 32 of his undergraduate LLB students on an optional finalyear Environmental Law module. Such an approach dovetails with UCL's 'Connected Curriculum' strategy which aims for students 'to learn through participating in research and enquiry', framed around six strands of 'connectivity'. The purpose of the Curriculum is for students to not only learn how to do what we do as academic researchers, but to do it with us as well. ${ }^{11}$ As an initial task, all 32 students in the class were allocated three universities in October 2017 by Steven and asked to complete a spreadsheet with information on any undergraduate environmental law modules those universities offered. Thereafter, in the run-up to Christmas 2017, the cohort split into four roughly equally sized groups: collecting data on postgraduate modules; conducting a literature review; reviewing and analysing the undergraduate data; and working on framing questions for an online survey. All of this work was compulsory, extra-curricular (in addition to seminar preparation work), and non-assessed. After February 2018, participation in the exercise was optional. 15 of the 32 students agreed to carry on working on the project. ${ }^{12}$ These students then divided their time between checking the data spreadsheets; summarising the

\footnotetext{
${ }^{8}$ Eloise Scotford and Steven Vaughan, 'Environmental Law and the Core of Legal Learning' OUP Blog (15 October 2018).

${ }^{9}$ Fiona Cownie and Anthony Bradney, 'An Examined Life: Research into University Legal Education in the United Kingdom and the Journal of Law and Society' (2017) 44 JLS 129, 129.

${ }^{10}$ Burke Johnson and Anthony Onwuegbuzie, 'Mixed methods research: A research paradigm whose time has come' (2004) 33 Educational Researcher 14.

${ }^{11}$ For deeper accounts of how the Connected Curriculum works in practice, see: Dily Fung, A Connected Curriculum for Higher Education (UCL Press 2017); and Vincent Tong and others, Shaping Higher Education with Students: Ways to Connect Research and Teaching (UCL Press 2018).

12 Two dropped out at a later date without any further contributions, which explains why there are only fourteen authors of this paper.
} 
literature; contacting academics to complete the survey; and later writing and commenting on drafts of the article.

\section{What Did We Learn About The Teaching of Environmental Law in the UK?}

Our website data shows that at 47 of the top 100 UK universities some form of environmental law is taught at the undergraduate (UG) level inside a law school. ${ }^{13}$ At no university in the UK is it compulsory to study environmental law during a UG law degree. This number $(n=47)$ is lower than that found in the 2002 UKCLE Report, where 59 universities offered UG environmental law in $2002 .{ }^{14}$ Of the 47 universities offering UG environmental law modules, 34 of them offer only one module in the subject (and the other 13 only two modules). $67 \%$ of UK UG environmental law modules are offered in the final year of study only; $13 \%$ in second year only, and the rest in either or both of those two years. This is broadly comparable to the picture in $2002 .{ }^{15}$

One of the reasons we wanted to do the online survey alongside the web searches was to add some detail about who teaches environmental law in the UK. In the survey we asked respondents not only about themselves but also about others teaching environmental law in their universities. Table 1 shows two peaks of when our respondents began teaching environmental law: one grouping with under 5 years of experience; and the other over 21 years of experience (with a couple having taught environmental law since the early 1980s). Such clusters may reflect different corollary peaks of interest in environmental law issues. ${ }^{16}$ The UKCLE Report identified the mid-1990s as the main start of environmental law teaching in the UK, with sporadic courses having begun in the 1960s, 1970s and 1980s. ${ }^{17}$ Interestingly, eight of those taking our survey indicated that their environmental law courses had begun in the last two years.

Table 1 - Length of Time Teaching Environmental Law ${ }^{18}$

\begin{tabular}{|l|l|l|l|l|}
\hline $0-5$ years & $6-10$ years & $11-15$ years & $16-20$ years & $21+$ years \\
\hline $14(29 \%)$ & $7(14 \%)$ & $5(10 \%)$ & $7(14 \%)$ & $15(31 \%)$ \\
\hline
\end{tabular}

In total, 109 individual teachers of environmental law were named in our 2018 survey. 88 had been identified in 2002 in the UKCLE Report. ${ }^{19}$ The 109 split, fairly evenly, between those in 'old' and those in 'new' universities (the same as in 2002). 66 of the 109 (61\%) were women. This is a statistically significant change since the UKCLE Report. ${ }^{20}$ Of the 38 universities covered in our survey, seven had only one teacher of environmental law

\footnotetext{
${ }^{13}$ We did not explicitly look for data on environmental law taught elsewhere in the university. This may be worthy of further study.

${ }^{14}$ UKCLE Report, 14. As far as we can tell, the most recent similar survey in the US was conducted in the early 1970s and has not been updated since. It found 64 universities offering environmental law. See: Frances Irwin, 'The Law School and the Environment' (1972) 12 Natural Resources Journal 278.

15 UKCLE Report, 29.

16 This is the same hypothesis put forward by the UCKLE Report authors: UCKLE Report, 20.

17 UKCLE Report, 20.

18 One survey respondent did not complete this question. This means that the percentages add up to $98 \%$. ${ }^{19}$ UKCLE Report, 16.

${ }^{20}$ We performed a chi square test on the underlying raw data, with the chi square value of 3.9452 and a $\mathrm{p}$ value of 0.047 .
} 
and eight had five or more. This is also a change since 2002, where there were more environmental law teachers on their own in university law schools. ${ }^{21}$

In only three instances did university websites indicate average environmental law UG class sizes. At the LSE this was 20 students; at UCL 24 students; and at Leeds 75 students. When we asked our survey respondents whether they thought the numbers of students taking environmental law at UG level was changing over time, the majority of those who replied (20 out of 36) thought there was no change; 8 thought numbers were increasing; and 8 thought numbers were decreasing. When we asked why our respondents thought their students chose (or did not choose) environmental law as an optional module of study, replies centred around three factors. The first went to topicality, or the increase in "front page environmental issues" [R33], the sense that environmental harms and challenges are now more in the minds of undergraduates than before: "news coverage around the Paris Agreement seems to bave encouraged sign up on my climate course" [R1]. The second went to employability, and the negative referents associated with taking environmental law over other options. The comments here were voluminous:

"It is not so attractive for students selecting their courses based on employment prospects and salary" [R18].

"[Students] do not see immediate job prospects" [R29].

"Some students may be put off the subject because it is seen as less serious and corporate than other modules. Perceived as wishy washy, a subject for lefties and those consumed by wanderlust, perhaps?” [R34]

"Students are interested but they don't see it as an area that leads to employment" [R46].

The shared impression among our respondents was that many of their students wanted well-paying, City of London lawyer jobs and that their students thought that taking environmental law would not help in securing those jobs. Here, employability is as much an organising force of modern day universities as our survey respondents seem to think it is of student preferences. ${ }^{22}$ Though the extent and operationalisation of the narratives differ, the modern UK university is keen to demonstrate 'value for money' for its students which in part comes from those students leaving the university employable (and hopefully already with employment offers). ${ }^{23}$ Rebecca Nedeva and Maria Boden ask whether, 'employability discourses may be adversely affecting pedagogies and curricula, to the disbenefit of students, institutions, employers, social justice and civil society. ${ }^{24}$ Our survey respondents certainly seem to think those discourses are impacting on environmental law student numbers. In this context, the nature and extent of how environmental law is valued or not valued (and in what ways) at different universities may be expressed in institutional attitudes to environmental law which shape, in turn, what students think of the subject. This institutional preferencing might be seen in hiring and promotion decisions, in which

\footnotetext{
${ }^{21}$ UKCLE Report, 17.

22 Sheila Slaughter and Gary Rhoades, 'The Neo-Liberal University' (2000) 6 New Labor Forum 73.

${ }^{23}$ Margaret Thornton, Privatising the Public University: The Case of Law (Routledge 2011); Chris Lorenz, 'If you're so smart, why are you under surveillance? Universities, neoliberalism, and new public management' (2012) 38 Critical Inquiry 599.

${ }^{24}$ Rebecca Boden and Maria Nedeva, 'Employing discourse: universities and graduate employability' (2010) $25 \mathrm{~J}$ of Education Policy 37.
} 
centres and institutes are allocated university funding, and in which modules get (and do not get) institutional approval to run.

The third theme among respondents as to why their students had chosen to study environmental law concerned the perception of the difficulty of the subject matter.

"When I asked why they studied environmental law, a majority responded it was because of the reputation of the module as 'easier' than some of the others" [R22].

"Its 'soft' appearance to some" [R28].

That environmental law was seen as "soft" was spoken to by the majority of survey respondents. Only one respondent said that the module was perceived as 'hard' (which, they said, impacted negatively on student numbers). Another commented that: " $A n$ interesting bit of feedback we sometimes get is that students found the module more challenging than they imagined" [R34].

We have three ideas to why environmental law might be seen as "soft". One possibility might be that the hesitancy that is sometimes seen in environmental law scholarship (discussed earlier on in this paper) bleeds through into how environmental law scholars present and frame the subject. A form and practice of reflexivity by some environmental law scholars might be perceived as 'softness' by students. This, of course, depends in part on students knowing something about environmental law scholarship and environmental law scholars before choosing or not choosing to study the subject. Another response might be that environmental law may thought to be seen as soft because of the liberal connotations of being 'an environmentalist'. That is, and to use Daniel Farber's language, is there a perception among law school students that there are more 'tree huggers' than 'bean counters' in environmental law? ${ }^{25}$ Our third, and related, response is that a perception of 'softness' may be linked to an idea that environmental law is more about values and less about (doctrinal) law. Here, we had also asked our survey respondents about how their students found studying environmental law. While we might need to take student feedback with a (decent) pinch of salt, ${ }^{26}$ a recurring theme was that while students of environmental law enjoyed the issues, the ideas, and the topicality, they found the law less enticing.

"They are less keen on the dense and technical statutory material" [R8].

"Students tend to focus on the environmental issues generally and not so much on the law" [R29].

"In general they don't like dull regulation, but who does?" [R43].

One respondent commented that, in their feedback, one student had asked him for "more environment and less law" [R36]. Our discussion so far has in some way taken for granted that 'softness' is a negative referent. But it may also be the opposite. Put another way, some students may stay clear of environmental law because they dislike its perceived 'softness';

\footnotetext{
${ }^{25}$ Daniel A Farber, Eco-pragmatism: making sensible environmental decisions in an uncertain world (University of Chicago Press, 1999).

${ }^{26}$ We note here the various studies which show how women, BAME academics, and LGBT+ academics are rated less well than straight, white men in student teaching evaluations. See the annotated bibliography maintained by the LSE here: https://blogs.lse.ac.uk/impactofsocialsciences/2017/03/08/newly-updatedfor-international-womens-day-gender-bias-in-academe-bibliography/
} 
and others may actively take the subject because of that same perceived quality (because they are interested in values and/or because they would like what they think is a law-lite module to study). Putting the reflexive liberalism of some environmental law scholars to one side, we would argue that the 'law' element of environmental law is just as dense, complex and challenging as in many other fields. What perhaps distinguishes environmental law is the extent to which in studying the subject one needs to unpick, unpack, and become immersed in a complex of dynamic and often unstable legal, social, economic, and political processes. ${ }^{27}$ As Liz Fisher might put it, environmental law is not soft, it is 'hot'. ${ }^{28}$ If students think otherwise, that is an error worth correcting.

\section{The Challenges in Teaching Environmental Law in the UK}

'The subject seems to have overwhelmed us. Virtually every law teacher - however broad his or her outlook - wants to introduce students to the specific material in the field and to provide some experience and familiarity with it. Yet every such attempt is an encounter with statutes of numbing complexity and detail.'

The above quotation from an environmental law scholar could have easily have come from our survey data. It did not. It was written in $1989 .{ }^{29}$ The challenges in teaching environmental law seem to have elements of universality through time. In the 2002 UKCLE Report, respondents identified the following as the four most significant challenges in teaching in environmental law: (i) the rapid pace of change in law and policy; (ii) the selection of appropriate course content; (iii) the interdisciplinary dimension to the subject; ${ }^{30}$ and (iv) the polycentric nature of the subject. ${ }^{31}$ Our survey respondents raised similar issues: the "quintessentially interdisciplinary" [R49] nature of environmental law; "understanding the science behind the law" [R3]; and "introducing students to the complexity of environmental problems" [R7]. The pace of environmental law was a common challenge: "it changes so quickly, requires constant updates" [R12]; "impossible to keep up with all areas within the field anymore" [R17]. Although, again, comments on pace have been made of environmental law since the $1980 \mathrm{~s},{ }^{32}$ and so there are elements of continuity and change at play.

However, not everyone agreed that the challenges in teaching environmental law were any different to teaching in other areas of law. A minority pushed back as to any distinctiveness: "Although there are always arguments put forward about coherence, complexity and definition, it really is no different to any other subject" [R16]. Such comments, and those that follow, made us reflect on the extent to which the scholarship exploring the nature and boundaries of environmental law is possibly over-egging the pudding. ${ }^{33}$

"Where does the subject begin and end? Different course tutors prioritise different issues, but both these challenges are found elsewhere too" [R19].

\footnotetext{
${ }^{27}$ Elizabeth Fisher, 'Environmental law as "hot” law' (2013) 25 JEL 347.

28 ibid.

${ }^{29}$ S Joseph Sax, 'Environmental Law in the Law Schools: What We Teach and How We Feel About It'

(1989) 19 Envtl L Rep 10251, 10251. See also: Joel Mintz, 'Teaching Environmental Law: Some

Observations on Curriculum and Materials' (1983) 33 J Legal Educ 94, 96.

30 This, admittedly, has been recognized since at least 1981 as a challenge. See: Guillermo Cano, 'Education in Environmental Law' (1981) 1 The Environmentalist 259.

${ }^{31}$ UKCLE Report, 36.

32 Mintz (n 29), 94.

${ }^{33}$ On which, see: Elen Stokes, 'Review of Eloise Scotford, Environmental Principles and the Evolution of Environmental Law, Oxford: Hart, 2017’ (2018) 81 MLR 920.
} 
"I don't buy the argument that environmental law is necessarily any more challenging than e.g. tort, contract. And even 'sleepy subjects' (if I may use that term) like constitutional and public law are presently undergoing dramatic changes" [R43].

Almost everyone who completed our survey commented, at some point, about the need to balance breadth of coverage with depth of analysis when teaching environmental law. Once again, little has changed since the UKCLE Report. In both our work and the UKCLE work from 2002, many teachers of environmental law talked about reducing the number of topics they covered to include more depth. ${ }^{34}$ This is worth thinking about. Is there an irreducible core to environmental law which students must cover and without which one cannot properly be said to have studied environmental law? The table of contents of the main environmental law textbooks would seem to indicate common areas of interest, but do these speak to a 'core'? Our data would suggest not, given how many academics regularly change their syllabi and how many have reduced the number of topics studied over time. As one respondent put it:

\section{"As I have gotten older, I have realized that I can do what I like (within limits) and that there doesn't have to be a neat intellectual coherency to what the students study with me in environmental law" [R33].}

In terms of the detail of the content covered, only 16 of the 47 universities offering UG environmental law put some form of topic list or detailed module overview onto their webpages. Analysis of these lists showed a wide approach to content, with common overlaps including climate change, regulation/governance, pollution controls, international issues, and enforcement. However, given the small sample size, we would be wary of taking much from this grouping save that most of our survey respondents also indicated that climate change had taken on a great prominence in their teaching over time. A smaller number of our survey respondents commented (in addition to the increase in focus on climate change) on the rise of "buman rights and rights for nature" [R8] in recent years. ${ }^{35}$ What also seemed common was a move from teaching UK environmental law ("definitely less purely national law" [R37]) to teaching environmental regulation at other scales and in other places. We were struck by how few respondents mentioned planning law as part of what they teach, given planning law teaching was the origin of many of the early environmental law courses. ${ }^{36}$

\section{Final Thoughts}

Let us end with some reflections on our data. There are two points that we have nibbled at the edges in our discussions but not explicitly addressed. The first is what the popularity of a discipline in teaching terms otherwise means for the health of that discipline. And the second is what our data and our responses to that data might require of environmental law educators. On the first, environmental law is rather marginal in a number of ways, depending on how one slices and dices marginality. ${ }^{37}$ For example, we know that when UK practising lawyers are asked directly to list the subjects they think are most important

\footnotetext{
${ }^{34}$ UKCLE Report, 45.

35 See: John Knox, 'Report of the Special Rapporteur on the Issue of Human Rights Obligations Relating to the Enjoyment of a Safe, Clean, Healthy and Sustainable Environment' (United Nations 2017).

36 UKCLE Report, 7 and 26.

37 On this, see: Fisher and others (n 2), 221-223.
} 
to practice, environmental law does not feature at all. ${ }^{38}$ Data from The Law Society shows that just $1.9 \%$ of solicitors put environmental law as their primary area of specialism. ${ }^{39} \mathrm{We}$ also know that only $2.1 \%$ of submissions to REF2014 (the UK's government-led assessment of research quality in univerisities) were for environmental law: by contrast, $11.6 \%$ were for company or commercial law; $9.7 \%$ for legal theory; and $7.7 \%$ for international law. ${ }^{40}$ And our own data shows a decline in provision of environmental law teaching and static student numbers. Whether we like it or not, size can matter and there may be radiating effects of environmental law being taught in fewer places with fewer students. Popularity might impact on health. One effect might be that fewer people in turn specialise in environmental law, either as academics or as lawyers. Another might be that universities make hiring, firing, and promotion decisions based on what they perceive to be the 'value for money' from environmental law education provision. Here, increasing emphasis in the UK on government assessments of 'research quality' might also be crowding out time and energy on teaching in favour of time and energy on scholarly outputs. The number of environmental law scholars and the provision of environmental law teaching on their own are not determinative of the health of the discipline, but our data contained some elements of existential angst. We seem to be at a place where environmental law educators and scholars are asking: do we matter?; where will our voices be heard and by whom?

We want to end by asking what the data we have set out requires of us as environmental lawyers (students and scholars). If we see legal education as a vehicle for regulatory and social change, ${ }^{41}$ and if we accept the multiple harms from our use of environment, then should we in the environmental law community be doing more to market environmental law as a subject of universal importance and worthy of study? This may seem like a special pleading for environmental law. And, in a way, it is. We are not, to be clear, saying that environmental law is more or less 'important' than other legal subjects. But we are asking what it might say about audiences for expertise, and about commitment to public service, ${ }^{42}$ if environmental law scholars primarily research environmental law but mostly (or only) teach subjects that are not environmental law (as our data showed in some instances). As Elen Stokes has observed, the teaching of environmental law is one of the, 'more mundane ways in which the discipline gets made. ${ }^{43}$ We may be disciplining the discipline if we have been in any way complicit in the decline in provision of environmental law teaching and static student numbers, or if we do not act in response to the data we have set out.

\footnotetext{
${ }^{38}$ LETR, 'Setting Standards: The Future of Legal Services Education and Training Regulation in England and Wales' (LETR Final Report 2013), 34.

${ }^{39}$ The Law Society, 'Categories of Work Undertaken by Solicitors' (January 2017), 2.

${ }^{40}$ Mark Davies, 'Changes to the training of English and Welsh lawyers: implications for the future of university law schools' (2018) 52 The Law Teacher 100, 115.

${ }^{41}$ Stanley Fish (and others) might disagree. See: Stanley Fish, Save the World on Your Own Time (OUP 2012)

${ }^{42}$ Maria Lee, 'Public Service, Environmental Law Academics and Brexit' (16 October 2018). Available at SSRN: https://ssrn.com/abstract $=3267300$

${ }^{43}$ Elen Stokes, 'Normal Chaos of Environmental Law' (Reimagining Environmental Law Conference Paper, University of Birmingham, January 2019).
} 